\title{
DISKRESI YUDISIAL: ANTARA KEADILAN DAN PENCITRAAN
}

\author{
Agus Nurudin \\ Fakultas Hukum Universitas Tujuh Belas Agustus 1945 \\ Jl. Pemuda No. 70 Semarang \\ Email: ags-nurudin@yahoo.com
}

\begin{abstract}
In practice law enforcement in Indonesia is still often the case the judge to deviate from the rules of law. In fact, the rules of law that is supposed to be a major consideration before making a decision. Deviation of the rules of the law such legal certainty, expediency and justice. Prejudice political, economic and moral in determining the verdict. Even reports by the media over the handling of a case also influence the judge's decision. The condition is exacerbated by the political influence of imaging in particular to case of corruption. When was handling matters of corruption, the mind set of judges has been patterned with penalties as severe by ignoring the rule of law, expediency and justice.
\end{abstract}

Keywords: Law Enforcement; Legal Certainty; Justice.

\begin{abstract}
Abstrak
Dalam praktik penegakan hukum di Indonesia masih sering terjadi hakim menyimpang dari kaidahkaidah hukum. Padahal, kaidah-kaidah hukum itulah yang seharusnya menjadi pertimbangan utama sebelum menjatuhkan putusan. Penyimpangan terhadap kaidah-kaidah hukum itu seperti kepastian hukum, kemanfaatan dan keadilan. Prasangka politik, ekonomi dan moral ikut menentukan putusan hakim. Selain itu, pemberitaan oleh media massa terhadap penanganan suatu perkara turut mempengaruhi putusan hakim. Kondisi tersebut diperparah dengan pengaruh politik pencitraan khususnya terhadap kasus-kasus korupsi. Ketika sedang menangani perkara-perkara korupsi, mind set hakim sudah terpola dengan hukuman yang seberat-beratnya dengan mengabaikan kepastian hukum, kemanfaatan dan keadilan.
\end{abstract}

Kata Kunci: Penegakan Hukum; Kepastian Hukum; Keadilan.

\section{A. Pendahuluan}

Akhir-akhir ini terjadi kecenderungan diskresi yudisial dalam penanganan perkara korupsi. Putusan-putusan hakim terhadap perkara korupsi mengalami trend meningkat mulai dari Pengadilan Negeri (PN) sampai di Mahkamah Agung (MA). Beberapa putusan hakim dalam perkara korupsi misalnya dalam perkara Angelina Patricia Pinkan Sondakh terkait kasus penggiringan anggaran di Kementerian Pendidikan dan Kebudayaan serta Kementerian Pemuda dan Olahraga Republik Indonesia, di mana oleh Pengadilan Tindak Pidana Korupsi (Tipikor) Jakarta diputuskan hukuman penjara selama 4 tahundan 6 bulan penjara serta diharuskan membayar denda Rp. 250 juta subsider 6 bulan penjara. Pada tingkat banding,
Pengadilan Tinggi Tipikor Jakarta memperkuat putusan Pengadilan Tipikor tersebut. Namun pada tingkat kasasi, MA menaikkan hukumannya menjadi 12 tahun penjara dan harus mengembalikan uang negara sebesar Rp. 12,5 miliar dan USD 2,3 juta.

Putusan berikutnya yang tampak adanya diskresi antara keadilan dan pencitraan adalah terhadap John Manuel Manoppo, mantan walikota Salatiga ini oleh Pengadilan Tipikor dihukum 3,5 tahun penjara, kemudian oleh Pengadilan Tinggi Tipikor diperberat menjadi 5 tahun penjara dan kemudian oleh MA diperberat lagi menjadi 8 tahun penjara dan diharuskan membayar denda sebesar Rp. 50.000.000,00 (Lima Puluh Juta Rupiah). Tendensi putusan 
akan semakin berat terbaca dari perkara korupsi mantan Kepala Korps Lalu Lintas Polri Inspektur Jenderal Djoko Susilo yang oleh Pengadilan Tipikor dihukum 10 tahun penjara, kemudian pada tingkat banding oleh Pengadilan Tinggi Tipikor diperberat menjadi 18 tahun penjara dan denda Rp 1 miliar serta diharuskan untuk membayar uang pengganti kepada negara sebesar Rp 32 miliar subsider 5 tahun penjara. Selain putusan-putusan tersebut di atas, masih terdapat beberapa putusan terhadap perkara korupsi yang sepertinya di-setting sedemikian rupa mulai dari putusan yang berat, semakin berat dan sangat berat.

Sementara itu dalam penegakan hukum (law enforcement), diupayakan agar tidak terjadi mind set hakim yang terpola pada putusan yang berat, semakin berat dan sangat berat. Hal ini terjadi karena dalam pelaksanaan tugasnya, seringkali hakim harus menghadapi tekanan dari pendapat masyarakat (public opinion). Seorang hakim harus memeriksa dan memutus suatu perkara di mana perkara tersebut merupakan subyek dari pemberitaan media massa dan menarik perhatian masyarakat misalnya menyangkut tokoh masyarakat maupun elit politik.

Adanya opini yang berkembang di masyarakat tentunya tidak boleh menjadi bagian dari unsur yang digunakan hakim dalam memeriksa dan memutus perkara tersebut, karena seorang hakim harus kebal terhadap opini masyarakat. Hakim tidak boleh terpengaruh oleh faktor-faktor eksternal, tetapi mengedepankan independensi demi tegaknya hukum. Faktorfaktor eksternal sebagaimana dikatakan Jerome Frank (1889-1957) bahwa manusia sekarang tahu bahwa hukum sebenarnya hanya terdiri dari putusan-putusan pengadilan, dan bahwa putusan-putusan itu tergantung dari banyak faktor. Adanya pemahaman bahwa kaidah-kaidah hukum yang berlaku mempengaruhi putusan seorang hakim, akan tetapi hanya sebagai salah satu unsur pertimbangan. Di samping itu, prasangka politik, ekonomi, dan moral ikut menentukan putusan para hakim. Selain itu juga simpati dan antipati pribadi berperan dalam putusannya.

Berdasarkan uraian di atas, dirasakan penting untuk mengkaji: kaidah hukum apa yang seharusnya digunakan oleh hakim dalam menentukan berat/ringannya hukuman; kaidah hukum manakah yang harus diprioritaskan oleh hakin dan apakah faktor non-hukum seperti faktor politik, ekonomi, kepentingan pribadi hakim dan pencitraan (image) dapat digunakan sebagai dasar dalam pertimbangan putusan hakim. ${ }^{1}$

\section{B. Pembahasan \\ 1. Kriteria Hukum yang Jelas}

Suatu hal yang patut dipertanyakan terkait dengan trend meningkatnya putusan terhadap perkara korupsi adalah apa kriteria para hakim Tipikor memutuskan berat ringannya hukuman dalam perkara korupsi? Pertanyaan ini patut dikemukakan mengingat putusan para hakim Tipikor terhadap perkara korupsi cenderung dengan pola yang sama yaitu memberatkan hukuman terhadap setiap orang yang terbukti bersalah melakukan korupsi. Pertanyaan lanjutannya adalah apakah hal itu disebabkan oleh posisi kasusnya serta kerugian negaranya sama?

Secara de facto yang terjadi adalah beragamnya kasus korupsi yang terjadi di Indonesia. Besarnya kerugian negara pun juga beragam. Berdasarkan realitas yang demikian itu, seyogyanya beragam juga berat ringannya hukuman penjara dijatuhkan kepada koruptor yang terbukti bersalah secara meyakinkan. Seharusnya, berat ringannya hukuman penjara terhadap koruptor tetap berdasarkan kepada kriteria hukum yang jelas, yaitu kepastian hukum, kemanfaatan dan keadilan. Jadi, bukan karena dibebani target oleh pimpinan atau instansi atasannya. Adanya kriteria hukum yang jelas tersebut, maka dapat diatasi bahaya timbulnya kesewenang-wenangan dalam penegakan hukum.2 Selain itu kepastian hukum, kemanfaatan, dan keadilan haruslah m e n d pat prioritas dala m mempertimbangkan berat ringannya hukuman.

Sebagaimana dikatakan H. L. A. Hart bahwa "Fidelity to law cannot be construed

\footnotetext{
1.Theo Huijbers, 1995, Filsafat Hukum Dalam Lintasan Sejarah,Yogyakarta, Kanisius, hlm 179.

2.Ibid., hlm. 165 .
} 
merely as fidelity to statutory law, but must be understood as fidelity to the principle of justice that underlie statutory law, bahwasanya kebenaran hukum tidak dapat ditafsirkan semata-mata sebagai kebenaran undang-undang, tetapi harus dipahami sebagai kebenaran prinsip keadilan yang mendasari undang-undang. ${ }^{3}$ Hal yang demikian oleh Satjipto Rahardjo dikatakan bahwa keadilan harus lebih luas dari sekedar keadilan peraturan atau formal justice. ${ }^{4}$

Ketika pengadilan (baca: para hakim) akan menegakkan hukum, maka harus selalu diingat bahwa keadilan adalah sebagai hakikat hukum. Bicara tentang hukum tetapi tidak terkandung keadilan di dalamnya jelas tidak bermakna, dan bahkan bisa membahayakan negara. Itulah yang oleh William Edward Glad Stone dikatakan bahwa "national injustice is the surest road to national dawnfall", ketidakadilan nasional adalah jalan yang paling pasti menuju kehancuran nasional. $^{5}$

Salah satu kemungkinan yang mesti diwaspadai adalah bergesernya hukum menjadi permainan. Permainan di sini adalah menurunkan derajat hukum itu sebagai alat untuk memenuhi dan memuaskan kepentingan sendiri. Jadi, tujuan hukum untuk memberikan keadilan (dispensing justice) telah mengalami kemerosotan menjadi permainan. ${ }^{6}$ Pengadilan merupakan benteng keadilan, bukan merupakan arena permainan. Oleh karena itu, orang-orang yang berada di lembaga peradilan itu adalah orang-orang yang tidak saja cerdas tetapi secara moral memang mereka baik, agar mereka tidak gampang menjadikan pengadilan sebagai arena permainan.

Relevan dengan hal tersebut Moh. Mahfud MD menyatakan, salah satu masalah yang sekarang timbul adalah terlepasnya sukma hukum yakni keadilan dari banyak proses penegakan hukum karena hukum kemudian lebih banyak dihayati sebagai persoalan teknis-prosedural semata. Banyak sekali orang yang melanggar etika dan moral, tetapi merasa atau bersikap seakan-akan tidak bersalah karena belum diproses secara hukum, tepatnya belum dibuktikan sebagai tindakan yang salah secara hukum oleh pengadilan. Padahal pada waktu yang bersamaan proses hukum di lembaga peradilan juga menghadapi masalah besar karena banyak dihinggapi oleh penyakit judicial corruption.

Akibatnya, hukum kemudian menjadi alat permainan untuk mencari kemenangan di dalam sengketa atau berperkara di pengadilan dan bukan untuk menegakkan keadilan, kebenaran, dan ketertiban di masyarakat. Penegakan hukum kemudian bermain atau terjebak di dalam permainan norma-norma tanpa mempedulikan manusianya sebagai subjek yang harus dilayani dengan hukum yang bersukmakan keadilan serta berlandaskan etika dan moral.

Hakim dalam menjalankan tugasnya tidak boleh dipengaruhi oleh kepentingan pribadi, misalnya target untuk dipromosikan yang biasanya didasarkan pada berapa banyak perkara yang telah ditangani, khususnya perkara korupsi. Ketika hakim berpola pikir demikian, dikuatirkan di dalam menangani perkara korupsi cenderung tidak objektif. Artinya ketika ada perkara korupsi yang sedang ditanganinya, maka kecenderungannya akan menjatuhkan hukuman yang seberat-beratnya, tidak lagi berdasarkan realitas dan bukti-bukti yang terungkap di dalam persidangan.

\section{Kekuasaan Kehakiman yang Merdeka}

Hakim di dalam menangani perkara harus sungguh-sungguh merdeka. Hal tersebut telah ditegaskan di dalam Pasal 24 ayat (1) Undang-Undang Dasar Negara Republik Indonesia yang setelah diamandemen berbunyi: "Kekuasaan kehakiman merupakan kekuasaan yang merdeka untuk menyelenggarakan peradilan guna menegakkan hukum dan keadilan". Selanjutnya dalam Ayat (2) dinyatakan bahwa "kekuasaan kehakiman dilakukan oleh

\footnotetext{
3. Satjipto Rahardjo, 2009, Penegakan Hukum:Suatu Tinjauan Sosiologis, Yogyakarta, Genta Publishing, hlm. vii.

4.Satjipto Rahardjo, 2006, Hukum dalam Jagat Ketertiban, Jakarta, Penerbit UKI Press, hlm. 18.

5. Tim Mitra Utama, 1993, Percikan Permenungan, Jakarta, hlm. 179.

6. Satjipto Rahardjo,2007, Biarkan Hukum Mengalir, Jakarta, Penerbit Buku Kompas, hlm. 61.

7. Moh. Mahfud MD, 2010, Konstitusi dan Hukum dalam Kontroversi Isu, Jakarta, PT Raja Grafindo Persada, hlm. 68-69.
} 
sebuah Mahkamah Agung dan badan peradilan yang ada dibawahnya dalam lingkungan Peradilan Umum, Peradilan Agama, Militer, Peradilan Tata Usaha Negara (PTUN) dan oleh sebuah Mahkamah Konstitusi”.

Putusan hakim harus berdasarkan hati nurani, bersih dan jujur dari seorang hakim. Putusan bukan karena tekanan publik, intervensi samar (quasi), publisitas untuk memuaskan keinginan publik. Putusan hakim tidak boleh didasarkan emosi karena prinsip independensi, imparsialitas dan fair trial. Artinya putusan hakim harus sungguhsungguh netral, tidak berpihak dan tidak boleh dikendalikan oleh situasi atau keadaan serta upaya pencitraan.

Pencitraan yang dilakukan oleh lembaga pengadilan pada umumnya dan Pengadilan Tipikor pada khususnya, disinyalir untuk mengembalikan kepercayaan masyarakat terhadap lembaga peradilan yang belakangan ini dinilai korup dengan tertangkap tangannya beberapa hakim melakukan korupsi. Ketika pencitraan itu yang mau dibangun oleh para hakim, maka ada kekuatiran hakim menjadi lupa akan kaidah-kaidah hukum, terutama keadilan (justice) yang menjadi pertimbangan utama dalam menjatuhkan berat ringannya hukum penjara terhadap seseorang. ${ }^{9}$

Bagaimana pun juga, keadilanlah yang seharusnya menjadi pertimbangan utama dalam menjatuhkan berat ringannya hukum penjara untuk semua perkara pidana termasuk perkara korupsi. Putusan-putusan pengadilan yang jauh dari rasa keadilan (sence of justice) cepat atau lambat akan mengakibatkan hilangnya kepercayaan masyarakat terhadap lembaga peradilan. ${ }^{10}$ Hukum mengatakan bahwa (1) hakim mengadili menurut hukum dengan tidak membedakan orang; (2) hakim wajib menggali, mengikuti dan memahami nilai-nilai hukum yang hidup dalam masyarakat; (3) dalam menimbang berat ringannya pidana, hakim wajib memperhatikan pula sifat-sifat yang baik dan yang jahat dari tertuduh. ${ }^{11}$

Berkaitan dengan hal tersebut di atas, maka tanggung jawab untuk menegakkan kebenaran prinsip keadilan nyata sekali ada pada para hakim. Eksistensi hakim yang oleh Lawrence M. Friedman dikelompokkan sebagai struktur hukum merupakan satu kesatuan yang disebut sebagai sistem hukum. Secara lengkap dikatakan bahwa ada tiga komponen sistem hukum dari perspektif ilmu sosial, yaitu struktur hukum (legal structure), substansi hukum (legal substance), dan budaya hukum (legal culture). Komponen struktur hukum adalah kelembagaan yang diciptakan oleh sistem hukum dan mempunyai fungsi untuk mendukung bekerjanya sistem hukum. Komponen struktur ini memungkinkan pemberian pelayanan dan penggarapan hukum secara teratur.

Oleh sebab itu, kaidah-kaidah hukum merupakan kriteria bagi hakim dalam memutuskan berat ringannya hukuman terutama kriteria keadilan, bukan kriteria politik, ekonomi, sosial budaya, kepentingan pribadi dan pencitraan. Moh. Mahfud MD menyatakan secara realistis di Indonesia saat ini fungsi hukum tidak bekerja efektif, sering dimanipulasi, bahkan jadi alat (instrumen efektif) bagi penimbunan kekuasaan. Komponen substansi adalah norma-norma hukum maupun oleh mereka yang diatur. Komponen kultural atau budaya hukum adalah berupa ide-ide, sikap-sikap, harapan dan pendapat tentang hukum. ${ }^{13}$

Menanggapi komponen sistem hukum itu, Kees Schuit menyatakan bahwa ada tiga

8. Fence M. Watu, "Kendala Hakim Dalam Menciptakan Kepastian Hukum, Keadilan, Dan Kemanfaatan Di Peradilan Peradata", Jurnal Mimbar Hukum, Vol. 25, No. 2, Juni 2013, hlm. 205-218.

9. Komisi Yudisial, "Mendorong Terwujudnya Kekuasaan Kehakiman Yang Merdeka", Buletin Komisi Yudisial, Vol. 3, No. 2, Oktober 2008, hlm 5.

10. Bambang Sutiyoso, "Mencari Format Ideal Keadilan Putusan Dalam Peradilan", Jurnal Hukum IUS QUIA IUSTUM, Vol. 17, No. 2, April 2010, hlm. 217-232

11. Satjipto Rahardjo, "Hukum dan Perilaku: Hidup yang Baik adalah Dasar Hukum yang Baik", Harian Kompas, 2009, 12. hlm. 82.

12. Moh. Mahfud MD, 2006, Membangun Politik Hukum, Menegakkan Konstitusi, Jakarta, LP3ES, hlm. 63.

13. Lawrence M. Friedman, 1975, The Legal System, A Social Science Perspective, New York, Russel Sage Foundation, hlm. 11-19. Lihat juga Gunter Teubner(ed.), Dilemas of Law in the Welfare State, 1986, New York, Walter de Gruyter, hlm. 13-27. Bandingkan juga dengan Esmi Warassih, 2005, Pranata Hukum Sebuah Telaah Sosiologis, Semarang, PT. Suryandaru Utama, hlm. 81-82. 
komponen sistem hukum, yaitu (1) unsur idiil, yang meliputi keseluruhan aturan, kaidah, pranata dan asas hukum; (2) unsur operasional yang terdiri atas keseluruhan organisasi dan lembaga-lembaga yang didirikan dalam suatu sistem hukum; dan (3) unsur aktual, yaitu keseluruhan putusanputusan dan perbuatan-perbuatan konkret yang berkaitan dengan sistem makna dari hukum, baik dari para pejabat maupun para warga masyarakat. ${ }^{14}$ Benar kata Roscoe Pound bahwa"The law, in its procedural as well substantive aspects, is essentially made and administered by persons whose views and interpretations are buffeted by the winds of change through the year, so that it has become a truism that the quality of justice depends more on the quality of the (persons) who administer the law than on the content of law they administer". 15 Bahwasanya problem hukum di negara-negara berkembang khususnya di Indonesia bukan hanya pada hukum itu sendiri tetapi pada kualitas manusia yang menjalankan hukum itu.

\section{Pedoman Perilaku Hakim}

Putusan hakim yang cenderung hanya mengejar target berapa banyak perkara yang dapat diputuskan terutama perkara korupsi bertentangan dengan pedoman perilaku hakim dan merupakan penyimpangan terhadap asas-asas hukum. Sesungguhnya Mahkamah Agung Republik Indonesia telah menerbitkan Surat Keputusan Nomor: KMA/104/SK/XII/2006 tanggal 22 Desember 2006 tentang Pedoman Perilaku Hakim. Pedoman perilaku hakim ini merupakan salah satu pedoman yang komprehensif sebagai salah satu acuan dan parameter dalam melakukan pengawasan terhadap perilaku hakim.

Perilaku hakim sangat tergantung pada beberapa aspek (1) Kejujuran intelektual; (2) Kepatuhan kepada hukum yang berlaku; (3) Transparansi kepemilikan harta dan asset; (4) Melaksanakan prinsip-prinsip kehati-hatian dalam menjalankan tugas; (5) Menghindari perilaku yang dapat mengurangi tingkat kepercayaan terhadap lembaga pengadilan. ${ }^{16}$

Menurut Bagir Manan, ada beberapa faktor yang mendorong para penegak hukum $\mathrm{kurang}$ memperhatikan atau mengesampingkan asas-asas hukum:

a. Terlalu menekankan pada pembuktian, sehingga melalaikan atau mengesampingkan cara-cara yang dibenarkan dalam memperoleh bukti atau bukti-bukti. Sadar atau tidak sadar praktik semacam ini termasuk dalam jargon "tujuan menghalalkan cara", (the end justifies the means).

b. Terlalu dipengaruhi oleh tekanan pendapat umum atau kelompokkelompok penekan (pressure groups) yang langsung atau tidak langsung memengaruhi penegak hukum yang semestinya netral (impartial), fair, dan hanya memutus menurut hukum. Di pihak lain, para penekan adalah pelopor yang memperjuangkan hak asasi manusia, negara hukum, dan demokrasi. Suatu bias atau anomali yang tidak mudah dicerna. Hal-hal tersebut tidak semata-mata didorong oleh tuntutan subjektif (seperti, interest), tetapi juga karena berbagai kondisi objektif yang menimbulkan keraguan pada publik atas ketulusan penegak hukum. ${ }^{17}$

Aparatur penegak hukum in casu hakim seyogyanya berbasiskan supremasi hukum (supremacy of law) dalam menegakkan hukum dengan 3 (tiga) cirri utama. ${ }^{18}$ Pertama

14. J.J.H. Bruggink, Rechtsreflecties, Grondbegrippen uit de Rechtstheorie, dialihbahasakan B. Arief Sidharta, 1999, Refleksi tentang Hukum,Bandung, PT. Citra Aditya Bakti, hlm. 140. Lihat juga B. Arief Sidharta, 2000, Refleksi Tentang Struktur Ilmu Hukum, Sebuah Penelitian tentang Fundasi Kefilsafatan dan Sifat Keilmuan Ilmu Hukum Sebagai Landasan Pengembangan Ilmu Hukum Nasional Indonesia, Bandung, Mandar Maju, hlm. 75-76.

15. Henry J. Abraham, 1993, The Judicial Process, Sixth Edition, Oxford University Press, dalam Frans Hendra Winarta, 2000, Bantuan Hukum, Suatu Hak Asasi Manusia Bukan Belas Kasihan,Jakarta, PT. Elex Media Komputindo Kelompok Gramedia, hlm.39-40.

16. Muhammad Rum Nessa,'Memperkokoh Integrasi Kualitas Kinerja Hakim Sebagai Salah Satu Pilar Aparat Peradilan", Artikel dalam Bagir Manan Ilmuwan dan Penegak Hukum (Kenangan Sebuah Pengabdian), 2008, Jakarta, Makamah Agung Republik Indonesia, hlm. 461.

17. Abdurrahman, 2008, Bagir Manan Ilmuwan dan Penegak Hukum (Kenangan Sebuah Pengabdian), Jakarta, Mahkamah Agung Republik Indonesia, hlm. 7.

18. Henry P. Panggabean, 2005, Fungsi Mahkamah Agung Bersifat Pengaturan (Rule making Power) Tahun 1966 2003, Edisi Pertama, Cetakan Pertama, Yogyakarta, Liberty,hlm. 12. 
adalah hukum harus berperan sebagai panglima, sehingga penegakan hukum (law enforcement) dapat diwujudkan tanpa memandang suku, agama, ras, golongan. Kedua, hukum harus sebagai titik tolak kegiatan (center of action). Hal ini berarti bahwa perbuatan hukum oleh penguasa atau individu harus dapat dikembalikan kepada hukum yang berlaku. Ketiga, perlakuan yang sama terhadap semua orang di muka hukum (equality before the law).

Diskresi yudisial yang cenderung pada putusan dalam rangka pencitraan membuktikan apa yang disinyalir oleh Muladi bahwa penegakan hukum merupakan sub sistem sosial, sehingga penegakannya dipengaruhi lingkungan yang sangat kompleks seperti perkembangan politik, ekonomi, sosial, budaya, hankam, iptek, pendidikan dan sebagainya. Sementara itu Hikmahanto Juwana menyatakan, penegakan hukum dikendalikan oleh pers. Ketika media massa dengan gencar memberitakan dan menyoroti suatu kasus, maka aparat penegak hukum serius melakukan penegakan hukum. Sebaliknya ketika tidak lagi disoroti media massa, maka penegakan hukum akan lambat laun menghilang.

Penegakan hukum yang profesional adalah penegakan hukum yang semata-mata mengedepankan kaidah-kaidah hukum t e r u t a m a ke a dila n, d e ngan mengesampingkan faktor-faktor lain seperti kepentingan kekuasaan (politik), ekonomi, opini masyarakat yang dipublikasikan pers dan kepentingan pribadi hakim. Hakim yang profesional adalah hakim yang dalam menjalankan tugasnya tidak terpengaruh dengan target kuantitas putusan dan pencitraan, tetapi mengutamakan kualitas putusan dengan berbasis kepada kaidahkaidah hukum.

\section{Simpulan}

Berdasarkan pembahasan di atas, maka dapat disimpulkan bahwa: hakim harus berpedoman pada kaidah-kaidah hukum yaitu kepastian hukum, kemanfaatan dan keadilan dalam menentukan berat/ringannya hukuman; Keadilan merupakan kaidah hukum yang harus diprioritaskan oleh hakim, sebab keadilan merupakan hakikat hukum; Faktor non-hukum seperti faktor politik, ekonomi, kepentingan pribadi hakim dan pencitraan (image) yang digunakan sebagai dasar dalam pertimbangan putusan hakim bertentangan dengan asas "equality before the law" dan asas legalitas.

\section{Daftar Pustaka}

Abraham Henry J, 1993, The Judicial Process, Sixth Edition, Oxford University Press.

Abdurrahman, 2008, Bagir Manan Ilmuwan danPenegak Hukum (Kenangan Sebuah Pengabdian), Jakarta, Mahkamah Agung Republik Indonesia.

Bruggink J,J.H, Rechtsreflecties, Grondbegrippen uit de Rechtstheorie, dialihbahasakan oleh B. Arief Sidharta, 1999, Refleksi tentang Hukum, Bandung, PT. Citra Aditya Bakti.

Friedman Lawrence M, 1975, The Legal System, A Social Science Perspective, New York, Russel Sage Foundation.

Huijbers Theo, 1999,Filsafat Hukum Dalam Lintasan Sejarah, Yogyakarta, Kanisius.

Juwana Hikmahanto, "Penegakan Hukum dalam Kajian Law and Development: Problem dan Fundamen bagi Solusi di Indonesia", Jurnal Varia Peradilan, No. 244, Maret 2006.

Komisi Yudisial, "Mendorong Terwujudnya Kekuasaan Kehakiman Yang Merdeka", Buletin Komisi Yudisial, Vol. 3, No. 2, Oktober 2008.

Maggalatung A.Salman, "Hubungan Antara Fakta, Norma, Moral, Dan Doktrin Hukum Dalam Pertimbangan Putusan Hakim", Jurnal Cita Hukum, Vol. 1, No.2, Desember 2014.

\footnotetext{
19. Muladi, 2002, Hak Asasi Manusia, Politik dan Sistem Peradilan Pidana,Semarang, Cet. II, Badan Penerbit Universitas Diponegoro, hlm. 69.

20. Hikmahanto Juwana, "Penegakan Hukum dalam Kajian Law and Development: Problem dan Fundamen bagi Solusi di Indonesia", Jurnal Varia Peradilan, No. 244 Maret 2006, hlm. 17-22.

21.A. Salman Maggalatung, "Hubungan Antara Fakta, Norma, Moral, Dan Doktrin Hukum Dalam Pertimbangan Putusan Hakim”, Jurnal Cita Hukum, Vol. 1, No.2, Desember 2014, hlm. 185-192
} 
MD Moh Mahfud, 2006, Membangun Politik Hukum, Menegakkan Konstitusi, Jakarta, LP3ES. 2010, Konstitusi dan Hukum dalam Kontroversi Isu, Jakarta, PT RajaGrafindo Persada.

Nessa Muhammad Rum, "Memperkokoh Integrasi Kualitas Kinerja Hakim Sebagai Salah Satu Pilar Aparat Peradilan", Artikel dalam Bagir Manan Ilmuwan dan Penegak Hukum (Kenangan Sebuah Pengabdian), 2008, Jakarta, Mahkamah Agung Republik Indonesia.

Panggabean Henry P, 2005, Fungsi Mahkamah Agung Bersifat Pengaturan (Rule making Power) Tahun 1966 2003, Edisi Pertama, Cetakan Pertama, Yogyakarta, Liberty.

Rahardjo Satjipto, 2006, Hukum dalam Jagat Ketertiban, Jakarta, Penerbit UKI Press.

Rahardjo Satjipto, 2007, Biarkan Hukum Mengalir, Jakarta, Kompas.

Rahardjo Satjipto,, 2009, Penegakan Hukum:Suatu Tinjauan Sosiologis, Yogyakarta, Genta Publishing.

Rahardjo Satjipto, 2009, Hukum dan Perilaku: Hidup yang Baik adalah Dasar Hukum yang Baik, Jakarta, Penerbit Buku Kompas.

Sutiyoso Bambang, "Mencari Format Ideal Keadilan Putusan Dalam Peradilan", Jurnal Hukum IUS QUIA IUSTUM, Vol. 17 No. 2, April 2010.

Sidharta B. Arief, 2000, Refleksi Tentang Struktur Ilmu Hukum, Sebuah Penelitian tentang Fundasi Kefilsafatan dan Sifat Keilmuan Ilmu Hukum Sebagai Landasan Pengembangan Ilmu Hukum Nasional Indonesia, Bandung, Mandar Maju.

Teubner Gunter (ed.), 1986, Dilemas of Law in the Welfare State, New York, Walter de Gruyter.

Tim Mitra Utama, 1993, Percikan Permenungan, Jakarta.

Warassih Esmi, 2005, Pranata Hukum Sebuah Telaah Sosiologis, Semarang, PT. Suryandaru Utama.

Watu Fence M., "Kendala Hakim Dalam Menciptakan Kepastian Hukum,
Keadilan, Dan Kemanfaatan Di Peradilan Peradata", Jurnal Mimbar Hukum, Vol. 25, No. 2, Juni 2013.

Winarta Frans Hendra, 2000, Bantuan Hukum, Suatu Hak Asasi Manusia Bukan Belas Kasihan, Jakarta, PT. Elex Media Komputindo Kelompok Gramedia.

Undang-Undang Dasar Negara Republik Indonesia Tahun 1945.

Undang-Undang Republik Indonesia Nomor 48 Tahun 2009 tentang Kekuasaan Kehakiman.

Surat Keputusan Mahkamah Agung Republik I $n$ d o n e s i a $\quad \mathrm{N}$ o $\mathrm{m}$ o $\mathrm{r}$ : KMA/104/SK/XII/2006 tanggal 22 Desember 2006 tentang Pedoman Perilaku Hakim. 